\title{
MODEL APLIKASI FIKIH MUAMALAH PADA FORMULASI HYBRID CONTRACT
}

\author{
Ali Murtadho \\ IAIN Walisongo Semarang \\ e-mail: amalridho@gmail.com
}

\begin{abstract}
Modern literatures of fiqh mu'ämalah talk alot about various contract formulation with capability of maximizing profit in shariah finance industry. This new contract modification is the synthesis among existing contracts which is formulated in such a way to be an integrated contract. This formulation is known as a hybrid contract or multicontract (al-'uqüd al-murakkabah). Some of them are, bay' bi thaman 'ajjil, Ijärah muntahiyah bi '1-tamlik dan mushārakah mutanāqisah. This study intends to further describe models of hybrid contract, and explore the shari'ah principles in modern financial institutions. This study found a potential shift from the ideal values of the spirit of shari'ah into the spirit of competition based shari'ah formally.
\end{abstract}

\section{[]}

Literatur fikih muamalah modern banyak membicarakan berbagai formulasi akad-akad yang mampu melegitimasi upaya memaksimalkan margin industri keuangan syari'ah. Akad-akad baru ini merupakan hasil sintesa akad-akad yang sudah ada sebelumnya yang diramu sedemikian rupa hingga menjadi akad yang terpadu, yang belakangan ini dikenal dengan istilah hybrid contract atau multiakad (al-uqūd al-murakkabah). Beberapa akad jenis ini adalah akad bay' bi thaman 'äjil, akad ijärah muntahiyah bi '-tamlīk dan akad mushārakah mutanāqișah. Penelitian ini bermaksud untuk mendeskripsikan lebih jauh model-model akad hybrid contract, dan mengeksplorasi kedudukannya dalam lembaga keuangan syari'ah modern. Penelitian ini menemukan adanya potensi pergeseran dari semangat mewujudkan nilai ideal syari'ah menjadi semangat berkompetisi dalam formalitas kesyariahan.

Keywords: $\quad$ hybrid contract, fikih muamalah, akad, muḍārabah

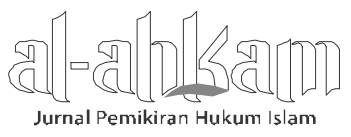


Ali Murtadho

\section{Pendahuluan}

Formulasi akad dalam fikih muamalah modern cukup variatif, namun masih berkutat dalam kerangka mencari legitimasi shar'i bagi pengembangan produkproduk perbankan syari'ah. Hal demikian sebagai upaya memacu akselerasi industri keuangan syari'ah untuk dapat berkompetisi dengan industri keuangan berbasis bunga. Literatur fikih muamalah modern sarat dengan berbagai formulasi formal akad-akad yang diperlukan untuk melegitimasi upaya memaksimalkan margin industri keuangan syari'ah. Ini ditandai dengan bermunculannya akadakad yang dikategorikan ghayr musammā (akad-akad baru yang belum disebut pada masa awal Islam) namun masih dalam kerangka formulasi klasik akad musammā (yang sudah diformulasikan secara rinci dalam literatur fikih klasik).

Akad-akad bentukan baru pada umumnya merupakan hasil sintesa akad-akad yang sudah ada sebelumnya yang kemudian diramu sedemikian rupa hingga menjadi akad yang terpadu. Akad-akad semacam ini belakangan dikenal dengan istilah hybrid contract atau multiakad (al-uqūd al-murakkabah). Contoh akad ini antara lain akad bay' bi thaman 'ājil, akad ijārah muntahiyah bi 'l-tamlīk dan akad mushārakah mutanāqișah. Akad bay' bi thaman 'äjil merupakan perpaduan antara akad bay' al-murābahah (jual beli dengan margin yang diketahui) serta akad qard (utang-piutang). Akad ijārah muntahiyah bi 'l-tamlīk merupakan perpaduan antara akad ijārah (sewa) dengan akad bay' (jual beli) atau akad hibah (pemberian). Akad mushārakah mutanāqișah merupakan perpaduan antara akad shirkah (kerja sama) dan akad ijārah (sewa). Contoh-contoh multiakad modern tersebut menarik untuk dikaji lebih lanjut. Mengingat di satu sisi terjadi progresivitas pemikiran Hukum Islam modern yang cenderung banyak mengkritik pola-pola aplikasi hukum formalis tekstualis, serta mengarah pada pemikiran hukum substansialis bahkan liberal. Seperti halnya pemikiran-pemikiran Hukum Islam Fazlur Rahman, Abdullāhi Ahmed al-Na'im, Muḥammad Shaḥrūr, dan sebagainya. Namun di sisi lain, dalam tataran aplikatif muncul formulasi akad modern dalam fikih muamalah yang kental dengan corak tekstualis formalistisnya. Tulisan ini, secara spesifik mengungkap bagaimana model aplikasi fikih muamalah (al-ijtihād al-tațbì fi 'l-mu'āmalah) pada formulasi hybrid contract atau multiakad (al-'uqūd al-murakkabah).

\section{Formulasi Akad dalam Fikih Muamalah Kontemporer}

Pembahasan masalah akad menjadi sentral kajian utama dalam fikih muamalah. Mengingat fikih muamalah merupakan Hukum Islam yang mengatur 
hubungan antar manusia satu dengan manusia lainnya dalam memperoleh, mengatur, mengelola dan mengembangkan māl (harta benda). Hubungan ini dilandasi oleh unsur saling rela ('an taräḍin) yang terejawantahkan dalam bentuk kesepakatan antara pihak-pihak yang terlibat, dengan sarana pengungkapan maksud yang jelas dan dapat dipahami oleh masing-masing pihak. Akad atau transaksi menjadi sarana penyelaras berbagai keinginan dan kepentingan para pihak. Kesesuaian suatu aktivitas ekonomi dengan aturan Islam dalam perspektif fikih muamalah akan dinilai dari akadnya. Begitu pentingnya posisi akad dalam fikih muamalah, sehingga ada yang mendefinisikan fikih muamalah sebagai sekumpulan akad-akad yang membolehkan saling tukar menukar manfaat.1

Pada dasarnya, berbagai jenis akad terbentuk secara alami seiring dengan perkembangan interaksi antar manusia atau pihak-pihak untuk memenuhi kebutuhan masing-masing menurut cara yang disepakati bersama. Selaras dengan karakteristik dasar bermuamalah yang bersifat inovatif, juga sejalan dengan kaedah alașl fi 'l-mu'ämalah al-ibāhahah illā an yadulla dalīl 'alā tahrīmihā (menurut asalnya semua bentuk muamalah hukunya boleh kecuali jika ada dalil yang menunjukkan keharamannya). ${ }^{2}$ Maka, sudah barang tentu ada akad-akad baru yang perlu menjadi obyek pembahasan fikih muamalah kontemporer.

Mengantisipasi banyaknya akad baru yang dimungkinkan bermunculan maka dalam fikih muamalah ada pengkategorian akad menjadi dua kategori. Pertama, 'Uqūd Musammā (akad-akad yang sudah ada namanya) yakni akad-akad yang oleh Syara' sudah diberi nama dan sudah ditetapkan ketentuan-ketentuan hukumnya. Kedua, 'Uqūd Ghayr Musammā (akad-akad selain yang sudah ada namanya) yakni akad-akad yang tidak dberikan namanya secara tertentu atau tidak ditentukan hukum-hukum tertentu oleh Syara'. ${ }^{3}$

Dewasa ini, perbincangan fikih muamalah lebih banyak tertuju pada penyediaan kerangka landasan Hukum Islam bagi upaya akselerasi berbagai industri keuangan syariah, terutama sektor perbankan. Mendominasinya tema perbankan dalam wacana fikih muamalah modern dapat dimaklumi mengingat perbankan sudah menjadi urat nadi perekonomian modern, sementara bunga bank masih proble-

\footnotetext{
${ }^{1}$ Rachmat Syafe'i, Fikih Muamalah (Bandung: Pustaka Setia, 2001), h. 15-16.

2Dewan Swan Syariah Nasional (DSN) Majelis Ulama Indonesia (MUI) hampir selalu menyertakan kaedah ini sebagai salah satu dasar fatwayang ditetapkan.

${ }^{3}$ Teungku Muhammad Hasbi Ash-Shiddieqy, Pengantar Fiqh Muamalah (Semarang: Pustaka Rizki Putra, 1999), h. 93.
} 
matik dari sisi fikih. Di sisi lain, industri keuangan berbasis bunga terus bergerak maju dengan produk-produk inovatifnya. Sementara itu, inovasi produk-produk lembaga keuangan syari'ah harus memiliki basis kesyari'ahan yang jelas.

Satu hal pokok yang membedakan perbankan syari'ah dari perbankan konvensional adalah pemakaian akad-akad legal formal secara fikih dalam setiap produk yang ditawarkan. Ketika diluncurkan berbagai produk funding, lending atau produk jasa lainnya, pertanyaan utama yang harus dijawab adalah akad apa yang dipakai pada produk-produk tersebut? Sedangkan dari sisi operasionalisasinya, perbankan syari'ah sama saja dengan perbankan konvensional, dimana keduanya termasuk lembaga keuangan yang berperan dalam menarik uang dari dan menyalurkannya ke dalam masyarakat. ${ }^{4}$

Keterlibatan fikih muamalah dalam konsepsi perbankan syari'ah dapat dijelaskan sebagai berikut. Kemunculan perbankan syari'ah disebabkan karena adanya persoalan fikih muamalah yang menyangkut bunga bank. Dari sisi fikih, muncul perdebatan tentang halal haramnya bunga bank. Ketika bunga bank diidentikkan dengan riba yang dilarang, maka bangkitlah semangat ijtihad untuk merumuskan sistem perbankan yang bebas bunga.

Perhatian utama fuqahä' modern lebih ditekankan pada bagaimana operasionalisasi perbankan dapat memberikan profitabilitas untuk keberlangsungan lembaga perbankan dengan memakai akad yang secara fikih muamalah diperbolehkan. Untuk itu, ada upaya intensif untuk mengkaji akad-akad yang ada dalam fikih muamalah klasik, dalam rangka merumuskan pengganti sistem bunga.

\section{Analisis Formulasi Akad Hybrid Contract}

Istilah hybrid contract mencuat belakangan ini ketika banyak diwacanakan sebagai bentuk akad baru mengiringi perkembangan perbankan syari'ah yang sangat pesat. Hybrid contract atau multiakad dalam bahasa Indonesia, sebagaimana dinyatakan oleh Hasanuddin, ${ }^{5}$ berarti akad berganda atau lebih dari satu akad. Multi akad diterjemahkan dari istilah fiqh al-uqūd al-murakkabah, artinya beberapa akad yang digabungkan menjadi satu nama. Hybrid contract merupakan satu akad, tapi di

4Ketut Rindjin, Pengantar Perbankan dan Lembaga Keuangan Bukan Bank (Jakarta: Gramedia Pustaka Utama, 2000), h. 13.

${ }^{5}$ Hasanudin menjabat sebagai wakil sekretaris Dewan Syari'ah Nasional (DSN) Majelis Ulama Indonesia (MUI), juga sebagai dosen Fakultas Syari'ah dan Hukum UIN Syarif Hidayatullah dan Institut Ilmu Al-Qur'an (IIQ) Jakarta. 
dalamnya dipadukan beberapa akad yang menjadi satu-kesatuan. Masing-masing akad memikiki akibat hukumnya sendiri-sendiri, tetapi dalam hybrid akibat-akibat hukum tersebut menjadi satu satu kesatuan. Pengikatan menjadi satu kesatuan ini dalam rangka memenuhi apa yang menjadi keinginan bersama kedua belah pihak yang tidak dapat dipenuhi jika memakai akad-akad yang terpisah-pisah. ${ }^{6}$

Dari sisi latar belakang pembentukannya, formulasi hybrid contract dipicu oleh semangat untuk mengembangkan perbankan syariah agar lebih kompetitif dari perbankan konvensional. Dunia perbankan konvensional sudah maju sedemikian pesat, karena sudah berusia berabad-abad. Produk-produk yang ditawarkannya pun sudah sedemikian variatif. Perbankan syari'ah yang didirikan dengan membawa misi Islam di bidang ekonomi untuk diterapkan dalam lembaga perbankan dituntut untuk dapat berpacu secara kompetitif mengejar ketertinggalan dari perbankan konvensional. Semangat kompetisi ini kadangkala dapat saja membius perbankan syari'ah sehingga lupa akan misi idealisnya.

Secara ideal, Bank Syari'ah mengemban misi untuk mengoperasionalisasikan fungsi perbankan dengan bersendikan keadilan, kejujuran serta misi penyemarakan sektor riil. Akad yang menjadi basis utamanya adalah mushārakah atau muḍārabah dengan prinsip bagi hasil dalam pola kemitraan. Namun, karena tuntutan profitabilitas dan didorong semangat akselerasi memperbesar market share, pertanyaan kekhawatiran yang muncul adalah apakah perhatian utama perbankan syari'ah bisa bergeser dari semangat mewujudkan misi ideal menjadi semangat berkompetisi dalam formalitas kesyari'ahan dengan menomorduakan misi ideal? Jawaban atas pertanyaan ini bisa diketahui dengan mencermati formulasi akadakad yang tergolong hybrid contract sebagai alternatif akad mushārakah dan mudarabah. Berikut ini diuraikan analisis formulasi beberapa akad yang tergolong hybrid contract yaitu akad murābaḥah atau bay' bi thaman 'ājil, ijārah muntahiyah bi 'l-tamlīk dan mushārakah mutanāqișah.

\section{Murābahah atau Bay' bi Thaman 'Ājil}

Pada bentuk murābaḥah, formulasinya diilhami oleh keinginan mendapatkan margin bagi bank syari'ah yang dapat mengimbangi atau lebih kompetitif dari pada bunga pada bank konvensional. Produk dengan skim murābaḥah merupakan

\footnotetext{
${ }^{6}$ Hasanudin, "Multi Akad dalam Transaksi Syari'ah Kontemporer pada Lembaga Keuangan Syari'ah di Indonesia: Konsep dan Ketentuan (Ḍawābit) dalam Perspektif Fikih", http://www. ekonomisyari'ah.org/, diakses 10 Oktober 2013, h. 2-4.
} 
produk yang paling popular dan banyak digunakan oleh perbankan Islam di seluruh dunia, termasuk Indonesia. Beberapa alasan yang mendasarinya adalah: pertama, murābahah merupakan suatu mekanisme pembiayaan investasi jangka pendek yang cukup memudahkan serta menguntungkan pihak bank Islam dibandingkan dengan konsep profit and loss sharing atau bagi hasil yang dianut oleh konsep muḍārabah dan mushārakah. Kedua, mark-up dalam murābahah ditetapkan sedemikian rupa yang memastikan bahwa bank Islam akan dapat memperoleh keuntungan yang sebanding dengan keuntungan berbasis bunga yang menjadi competitor bank-bank Islam. Ketiga, murābahah menjauhkan ketidakpastian pendapatan dari bisnis-bisnis berbasis profit and loss sharing. Keempat, murābahah tidak memungkinkan bank-bank Islam untuk mencampuri manajemen bisnis karena bank bukanlah mitra si nasabah, sebab hubungan mereka dalam murābaḥah adalah hubungan antara kreditur dan debitur. ${ }^{7}$

Sesuai ketentuan fikih, akad murābaḥah dilaksanakan setelah barang secara prinsip dimiliki oleh bank dan bank tidak boleh melakukan pengikatan (menjual barang kepada nasabah), sementara barang tersebut belum dimiliki bank. ${ }^{8} \mathrm{Ke}-$ tentuan ini secara formulatif teoritis untuk meng"halal"kan aplikasi hybrid contract secara fikih di mana barang yang belum menjadi tanggungan seseorang tidak boleh ia jual lebih-lebih mendapatkan labanya. ${ }^{9}$ Ketentuan murābaḥah dalam aplikasi murābaḥah -agar secara formal terhindar dari apa yang dilarang dalam Hadis di atas- menjadi rumit dan kurang praktis serta kurang mengantisipasi kemungkinan aplikasinya yang tidak seratus persen tepat sesuai ketentuan. Bahkan, bisa saja terjadi bank syari'ah ketika meng-akad-wakālah-kan pembelian aset kepada nasabah mengharuskan nasabah membelinya atas namanya sendiri bukan atas nama bank,10 sehingga secara fikih kepemilikan asset tersebut dari awal sudah menjadi milik nasabah. Lantas bagaimana bank dapat menjual kembali asset tersebut kepada nasabah?

\footnotetext{
${ }^{7}$ Nurul Huda \& Mohamad Heykal, Lembaga Keuangan Islam Tinjauan Teoritis dan Praktis (Jakarta: Kencana, 2010), h. 43-44.

8Ibid., h. 44.

'Waḥbah al-Zuhaylī, al-Mu'āmalah al-Māliyyah al-Mu'ạșirah Buhūth wa Fatāwā wa Hulūl (Beirut: Dār al-Fikr, 2002) h. 489.

10Sebagaimana disebutkan dalam Pedoman Akad Penyaluran Dana pada Akad Pembiayaan KPRBTN Syari'ah bank dengan akad ini memberikan kuasa kepada nazabah untuk membeli dan menerima Rumah tersebut serta menandatangani Akta Jual Beli atas namanya sendiri langsung dengan Pemasok/Pengembang".
}

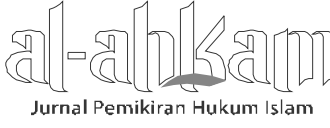


Ketentuan secara fikih akad murābaḥah harus merupakan akad jual beli riil sebagaimana tertuang pula dalam fatwa DSN-MUI juga dapat tidak dilaksanakan ketika Bank Syari'ah dituntut lebih memudahkan menyalurkan pembiayaan multiguna. Idealnya pembiayaan bank harus dipastikan untuk pembelian komoditas tertentu. Namun, kadangkala persyaratan nasabah harus menunjukkan bukti kuitansi pembelian dipermudah bahwa secara formal kuitansi tersebut menjadi urusan bank. ${ }^{11}$

Lebih dari itu, meski secara formal skim murābaḥah perbankan syari'ah sesuai dengan akad yang dibenarkan dalam muamalah Islam, namun substansi operasionalisasinya tidak dapat dilepaskan dari pengaruh praktik bunga bank konvensional. Sebagaimana diungkap M. Nadratuzzaman Hosen, pada skim konvensional maupun murābaḥah, tingkat harga cicilan barang menentukan tingkat keuntungan Bank. Cicilan ini dipengaruhi oleh harga pokok barang, harga barang yang dibeli nasabah serta lamanya cicilan dan besarnya Down-Payment (DP). Bahkan pada skim murābaḥah, tingkat suku bunga dan juga waktu pencicilan menjadi menjadi acuan utama bagi penetapan besarnya margin penjualan pada harga barang yang dibeli nasabah. Dan juga tingkat cicilan bersifat tetap untuk jangka waktu tertentu. Oleh karena itu, pihak bank lebih senang jika waktu cicilan (pelunasan) kurang dari sepuluh tahun daripada yang waktu cicilannya di atas sepuluh tahun. Hal ini disebabkan adanya resiko nilai uang yang terkait dengan waktu juga karena adanya kemungkinan tidak klopnya asset dan likuiditas akibat perubahan yang terjadi pada besaran margin dari hasil pembiayaan dan bagi hasil yang harus dibayarkan kepada pihak ketiga yang berasal dari dana-dana pihak ketiga. ${ }^{12}$

Kesadaran akan kekurang-syari'ahan murābahah juga dirasakan secara internasional. Untuk menghindari praktik murābaḥah yang dapat menyimpang dari prinsip syari'ah, di Sudan murābaḥah dipraktikkan secara sederhana sebagaimana yang terjadi dalam konsep fikih klasik. Memang pada perbankan syari'ah di Sudan akad kekhasan akad yang berbeda dari perbankan syari'ah pada umumnya, antara lain adalah praktik murābaḥah sederhana. Akad murābaḥah sederhana ini merupakan bentuk akad di mana penjual memang memasarkan barang dagangannya kepada pembeli dengan harga jual yang merupakan harga perolehan barang

\footnotetext{
11Wawancara dengan Elam, marketing Bank Jateng Syari'ah tanggal 4 Juli 2013

12M. Nadratuzzaman Hosen, Mushārakah Mutanāqiṣah, dalam http://www.ekonomisyari'ah.org, diakses 10 Agustus 2013, h. 12.
}

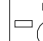

Jurnal Pemikiran Hukum Islam
Volume 23, Nomor 2, Oktober 2013 
ditambah dengan margin keuntungan yang diinginkan oleh penjual. Praktik murābahah yang dilaksanakan pada perbankan syari'ah di Sudan memiliki pola implementasi yang berbeda dibandingkan dengan praktik pembiayaan murābahah yang ada dan dilaksanakan di perbankan Islam di negara lain. Beberapa perbedaannya antara lain adalah bahwa bank Islam betul-betul memiliki persediaan barang yang akan dijual, ada pembatasan margin keuntungan dari Bank Islam, di samping ada juga pembatasan portofolio pembiayaan. ${ }^{13}$

Perbedaan dalam praktik pembiayaan murābaḥah yang dilakukan di Sudan dibandingkan dengan yang dipraktikkan di negara lain dikarenakan di Sudan juga terletak pada adanya pemikiran bahwa akad murābahah bukanlah akad utama yang harus dipraktikkan oleh perbankan Islam. Karena akad utama dalam perbankan Islam semestinya berupa akad berbasis bagi hasil yang merupakan prinsip utama dalam konsep ekonomi Islam. Pandangan yang ada dalam dunia perbankan Islam di Sudan ini memiliki keselarasan dengan pandangan yang disampaikan oleh M. Taqi Usmani dalam bukunya An Introduction to Islamic Finance, sebagaimana dikutip oleh Nurul Huda dan Mohamad Heykal, bahwa murābahah semestinya bukan merupakan salah satu bentuk pembiayaan yang diutamakan dalam konsep perbankan Islam, tetapi hanya merupakan jalan termudah untuk menghindari konsep bunga. Instrumen akad murābaḥah hanya layak digunakan sebagai suatu langkah darurat sementara ketika suatu negara atau suatu sistem ekonomi sedang berada pada fase awal transformasi sistem ekonomi dari sistem konvensional menjadi sistem ekonomi Islam dan pemakaiannya perlu dibatasi hanya untuk kondisi ketika instrumen muḍārabah dan juga mushārakah belum dapat diterapkan. Di samping itu, murābahah juga hanya merupakan bentuk pembiayaan yang hanya boleh dilaksanakan setelah memenuhi seluruh persyaratan secara Islam yang ditetapkan oleh ulama. Bila persyaratan tersebut tidak dapat dipenuhi, maka hakikatnya konsep murābaḥah tidak lagi sesuai dengan Islam. Oleh karena itu, dalam rangka mengikuti karakteristik kesyari'ahan, pertama-tama perbankan Islam diharapkan memiliki persediaan akan barang yang dijual agar tidak terjadi hal yang diharamkan sesuai dengan Islam, yaitu perbankan melakukan penjualan barang yang sebenarnya barang itu tidak dimilikinya. Sharia High Supervisory Board (SHSB) atau Dewan Pengawas Tinggi Syari'ah Sudan juga berusaha mendorong dunia perbankan Islam di Sudan untuk menggunakan akad utama

${ }^{13}$ Nurul, Lembaga Keuangan, h. 131-133. 
yang lebih seuai dengan prinsip islam dalam dunia perbankan islam, yaitu akad berbasis bagi hasil atau muḍārabah dan mushārakah. Berbagai upaya ini ikut mempengaruhi proporsi akad murābaḥah di perbankan Islam di Sudan menjadi berada di bawah $50 \%,{ }^{14}$ berbeda dengan yang ada di perbankan syari'ah pada umumnya di mana pembiayaan berbasis murābahah sangat dominan dan muḍarabah hanya seperti asesoris penghias saja

\section{Ijārah Muntahiyah bi 1-Tamlik (IMBT)}

Hybrid contract yang berbentuk ijārah muntahiyah bi 'l-tamlīk formulasinya juga dalam rangka men"syari'ah" kan konsep sewa beli dalam lembaga keuangan konvensional. Sejarah muncunya ijārah muntahiyah bi 'l-tamlīk, merujuk ke Undang-Undang Inggris dalam mewujudkan apa yang dinamakan jual beli sewa atau sewa pemindahan kepemilikan untuk mendorong para nasabah membeli secara kredit di bidang perdagangan, kemudian untuk menjadikan laku produkproduk industri dengan menjual berbagai perabotan, peralatan, mesin-mesin di mana kepemilikan barang masih tetap di tangan penjual sampai terbayar semua angsuran. Para pakar hukum Mesir menganggap, jenis ini sebagai jual beli dengan kredit. Sistem Inggris menyederhanakannya dengan menyebutnya sebagai kontrak sewa. Sedangkan di Perancis, digolongkan sebagai transaksi yang terstruktur (murakkab) dalam dua transaksi yang terpisah, yakni transaksi sewa diiringi jual beli. Praktek yang terjadi di Perancis ini yang kemudian ditetapkan oleh fikih Islam kontemporer, dengan melarang adanya dua transaksi dalam satu transaksi, atau dua jual beli dalam satu transaksi jual beli. Sewa yang disertai pemindahan kepemilikan sebagaimana ada di Barat tidak diperbolehkan, sedangkan yang diperbolehkan adalah adanya dua akad yang masing-masing berdiri sendiri. Akad yang kedua didasarkan pada janji yang ada pada akad yang pertama. 15

Firdaus Muhammad Arwan juga mengungkap bahwa ijārah muntahiyah bi' ltamlīk merupakan konstruksi perjanjian sewa beli yang dianggap sesuai dengan syari'ah. Sewa beli merupakan salah satu bentuk perjanjian campuran antara jualbeli dan sewa menyewa dan dalam praktek sering disamakan dengan leasing. Ulama menilai perjanjian sewa beli ini bertentangan dengan prinsip-prinsip syari'ah, karena dianggap mengumpulkan dua akad dalam satu akad yang dilarang

${ }^{14}$ Ibid., h. 133-134.

15Wahbah, al-Mu'āmalah al-Māliyyah, h. 396.

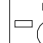

Jurnal Pemikiran Hukum Islam
Volume 23, Nomor 2, Oktober 2013 
oleh Rasulullah. Namun karena perjanjian ini telah marak dipraktikkan oleh masyarakat dan dipandang banyak manfaatnya, maka dicari solusi agar perjanjian tersebut ditolerir tetap dapat dilaksanakan, dengan tidak bertentangan dengan prinsip-prinsip syari'ah. Upaya ini memunculkan konsep ijärah muntahiyah bi' ltamlīk atau "ijärah wa iqtinā'”' sebagai bentuk hybrid contract yang dipandang sesuai dengan syari'ah. ${ }^{16}$

\section{Mushārakah Mutanāqișah}

Hybrid contract yang berbentuk mushārakah mutanāqișah diilhami oleh kesadaran akan kelemahan hybrid contract sebelumnya dari sisi kesyari'ahan. Perbankan Islam memakai akad-akad fikih, utamanya hybrid contract untuk menghindari riba atau rente. Akad yang paling umum dipakai adalah bay' bi thaman 'ājil atau akad murābaḥah. Belakangan, akad ini banyak diperdebatkan dari sisi kesyari'ahan. Muncul kemudian gagasan formulasi hybrid contract berupa mushārakah mutanāqiṣah yang diangap lebih menenangkan dan lebih mematuhi syari'ah. Mushārakah mutanāqișah adalah kombinasi tiga akad yaitu mushārakah, ijārah dan bay'. Mushārakah mutanāqișah merupakan kontrak partnership antara kedua pihak di mana satu partner secara berangsur-angsur membeli keseluruhan bagian properti. ${ }^{17}$

Dari sisi historis, sebagaimana diisyaratkan oleh para pakar fikih muamalah modern, kajian awal terformulasikanya mushārakah mutanāqișah dilakukan oleh Sāmī Ḥasan Ahmad Hamūd dalam disertasinya yang berjudul Tațīr al-a'māl alMashrafiyyah Bimā Yattafiq wa 'l-Sharīah al-Islämiyyah, dalam rangka memperoleh gelar Doktor di Universitas Kairo tanggal 30 Juni 1976. Mushārakah mutanāqișah ini pertama kali dipraktekkan di Mesir, kemudian dipakai pula di bank-bank Islam di negara-negara Arab dan yang lainnya. ${ }^{18}$

Dengan demikian, berbeda dengan bentuk-bentuk hybrid contract yang lain, mushārakah mutanāqișah dari sisi sumber kemunculannya relatif lebih idealis,

\footnotetext{
16Firdaus Muhammad Arwan, Ijārah Muntahiyah bi '-Tamlīk Sebagai Konstruksi Hukum Perjanjian Sewa Beli dalam Ekonomi Islam, dalam http://www.badilag.net, diakses 10 Agustus 2013, h. 1.

${ }^{17}$ Noor Mohammad Osmani dan Md. Faruk Abdullah, "Mushārakah Mutanāqisah Home Financing: A Review of Literatures and Practices of Islamic Banks In Malaysia" dalam International Review of Business Research Papers Vol. 6. Number 2. July 2010, h. 272-273.

${ }^{18}$ Ismāîl Shindī, "al-Mushārakah al-Mutanāqișah fi l-'amal al-Mașrafi '-Islāmī-Ta'șil wa Ḍabț", paper ilmiah pada Mu'tamar al-Iqtișād al-Islāmī wa a'māl al-Bunūk (Palestina: Universitas al-Khalīl, 2009).
}

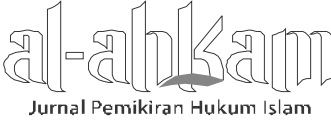


karena berasal dari kajian akademis berupa disertasi yang tentunya telah melewati uji kelayakan yang cukup ketat. Lebih dari itu, yang melatarbelakangi formulasinya adalah rasa keprihatinan terhadap berbagai bentuk Hybrid contract yang belum dapat merepresentasikan substansi keadilan yang menjadi prinsip yang dituju daalam aturan-aturan Fikih muamalah.

Bentuk akad seperti mushārakah mutanāqișah lebih merepresentasikan beberapa tujuan disyariatkannya akad secara syari'ah yakni yang menyangkut keadilan dan kebersamaan meski belum memenuhi tujuan kemudahan dan kepraktisan, sebagaimana diteorisasikan oleh al-Khālifi. Dengan mengacu pada sumber-sumber syari'ah baik al-Qur'an maupun Hadis Nabi, Riyāḍ Manșūr alKhālifi merumuskan prinsip-prinsip yang menjadi tujuan disyariatkannya berbagai transaksi bisnis atau muamalah Islam menjadi lima: yaitu: Pertama, prinsip keadilan (al-'adālah), lawan dari kezaliman (al-ẓulm). Kedua, prinsip kejujuran dan transparansi (al-șidq wa 'l-bayān), lawan dari kebohongan dan penyembunyian fakta (al-kidhb wa 'l-kitmān). Ketiga, prinsip perputaran harta (al-tadāwul) lawan dari penumpukan harta (al-kanz). Keempat, prinsip kebersamaan, persatuan dan tolong menolong (al-jamā'ah wa 'l-i'tiläf wa 'l-ta'āwun), lawan dari perpecahan, perselisihan dan saling bertolak belakang (al-furqah wa 'l-ikhtilāf wa 'l-tadābur). Kelima, prinsip memberi kemudahan dan menghilangkan kesulitan (al-taysìr wa raf al-haraj).19

Dapat disimpulkan di sini bahwa formulasi hybrid contract dari sisi latar belakang perumusannya didorong oleh semangat mengembangkan perbankan syari'ah dengan tetap memiliki cantolan fikih. Ketika akad tunggal mushārakah atau muḍārabah kurang fleksibel untuk diterapkan dan kurang menjamin keuntungan dan perkembangan bank syari'ah, diformulasikanlah hybrid contract berupa bay' bi thaman 'ājil atau murābahah kombinasi sebagai kompetitor pinjaman berbasis bunga. Demikian juga ijārah muntahiyah bi 'l-tamlīk dimunculkan sebagai konpetitor akad sewa beli yang disyari'ahkan lewat hybrid contract. Pengembangan berikutnya dilatarbelakangi oleh berbagai kritik kesyari'ahan atas hybrid contract sebelumnya, sehingga ada keinginan untuk membuat hybrid contract yang lebih sebagai merepresentasikan nilai-nilai syari'ah.

\footnotetext{
${ }^{19}$ Riyaḍ Manșūr al-Khālifi, "Al-Maqāṣid al-Shar'iyyah wa Atharuhā fì Fiqh al-Mu'āmalat alMāliyyah”, dalam Majalah Jāmi'ah al-Mālik 'Abd al-'Azīz, al-Iqtiṣād al-Islāmī, 17,1, 2004, h. 28.
}

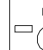

Jurnal Pemikiran Hukum Islam
Volume 23, Nomor 2, Oktober 2013 


\section{Model Aplikasi Fikih Muamalah pada Formulasi Hybrid Contract}

Kecenderungan aplikasi Fikih muamalah pada formulasi hybrid contract lebih nampak sebagai model aplikasi fikih dalam bentuk takhayyur, ${ }^{20}$ yang tidak terikat pada mazhab tertentu tetapi lebih memilih mana pendapat klasik yang seuai dengan alasan tertentu. Buktinya nampak dalam variasi bentuk hybrid contract di berbagai negara Muslim. Meskipun masyarakat Muslim di Malaysia memiliki mazhab pemikiran yang sama dengan masyarakat Muslim Indonesia, yaitu mazhab Syafi'i, tetapi beberapa aplikasi konsep Islam dalam perbankan Islam di Malaysia dan Indonesia dapat saja berbeda. ${ }^{21}$

Perbankan Islam di Malaysia misalnya, memiliki beberapa jenis akad yang ditawarkan kepada nasabah yang yang unik yang kadang berbeda dengan yang ada di negara lain. Akad yang khas ada di Malaysia misalnya akad bay' al-'inah, akad ini merupakan bagian dari akad jual beli di mana pihak penjual melakukan penjualan asetnya kepada pembeli denga janji untuk melakukn pembelian kembali dengan pihak yang sama. Dapat dikatakan bahwa bay' al-'inah merupakan penjualan tunai yang dianjutkan dengan pembelian kembali barang tersebut secara tangguh. Prosesnya adalah nasabah melakukan penjualan asetnya ke bank dengan harga tertentu, bank melakukan pembayaran dengan harga tersebut kepada pihak nasabah. Bank lalu melakukan penjualan kembali aset tersebut kepada nasabah dengan melakukan penambahan margin keuntungan. Nasabah membayar harga aset tersebut ditambah dengan margin keuntungan yang telah disepakati sesuai dengan kesepakatan yang ada. ${ }^{22}$

Akad bay' al-'inah tersebut mirip dengan konsep pinjaman tunai dengan adanya jaminan aset pada bank konvensional di mana perbedaannya terletak pada akadnya dan nasabahnya mendapatkan dana tunai. Jual beli dengan bay' al-inah ini banyak diijinkan oleh ulama Malaysia. Akan tetapi, sebagian besar ulama yang ada di Timur Tengah dan Indonesia banyak berpendapat bahwa transaksi dengan bay' al-'inah tidak sesuai dengan Islam. Apalagi dari empat mazhab mayoritas yang banyak dipakai oleh umat Islam, hanya mazhab Syafi'i yang mengijinkan akad bay

\footnotetext{
${ }^{20}$ Dalam konsep Noel J. Coelson ada empat bentuk aplikasi Hukum Islam modern yaitu Siyāsah, takhayyur, tatbiq dan tajdiīd. Lihat: Amir Muallim dan Yusdani, Konfigurasi Pemikiran Hukum Islam (Yogyakarta: UII Press, 1999), h. 16.

${ }^{21}$ Nurul, Lembaga Keuangan, h. 137.

22 Ibid,, h. 138-139.
} 
al-inah. Uniknya, Indonesia sebagai negara yang juga mayoritas pemakai mazhab Syafi'i justru menganut pendapat yang hampir sama dengan mayoritas ulama di Timur Tengah, yaitu bay' al-'inah dilarang dipakai. ${ }^{23}$

Dipilihnya pendapat fuqahä' klasik tertentu didasarkan pada tujuan yang bervariasi pula. Di Malaysia didorong oleh tujuan akselerasi perbankan syari'ah secara aresif dan inovatif maka cenderung dipilih pendapat-pendapat yang longgar yang dapat mengakomodasi kompleksitas produk perbankan. Karenanya, hampir semua produk pembiayaan yang ada pada perbankan konvensional juga dikembangkan di dalam perbankan Islam di Malaysia. Menariknya lagi, rata-rata produk pembiayaan yang ada pada perbankan Islam di Malaysia tidak menggunakan akad berbasis bagi hasil, tetapi lebih memakai akad berbasis margin jual beli seperti murābaḥah atau bay' bi thaman ajjil.24 Berbeda dengan di Indonesia atau Sudan dan Timur Tengah pada umumnya yang memilih pendapat fuqah $\bar{a}^{\prime}$ klasik dengan alasan pentarjihan sisi kesyari'ahannya.

Namun, secara umum ada kesamaaan kecenderungan corak formulasi hybrid contract, yakni corak formalistis tekstualis. Corak formalistis nampak pada berbagai ketentuan atau rambu-rambu pelaksanaannya yang sagat berpegang pada formalitas syarat rukun akad yang sudah diformulasikan pada Fikih muamalah klasik. Corak tekstualis karena perhatian besarnya terhadap penafsiran literal teks hukum yang sudah ada. Karena perhatian besarnya pada tekstualitas nas, maka corak tekstualis ini seakan tidak menyediakan ruang yang mendukung bagi pertimbangan etis, artinya suatu aturan akan dianggap sebagai hukum sepanjang secara teknis dideduksi dari sumber naș. ${ }^{25}$

Dapat ditambahkan di sini bahwa aplikasi fikih muamalah kontemporer juga masih memakai pertimbangan tațbiq (aplikasi hukum) melalui prinsip bidang atau kewenangan (al-așliyyah). Melalui pertimbangan ini, hukum syara' terpilah menjadi dua kapling, yaitu bidang ibadah dan bidang muamalah. Jika termasuk bidang ibadah, maka berlaku kaedah bahwa suatu ibadah itu pada dasarnya batal hukumnya kecuali ada dalil yang memerintahkannya. Sedangkan, jika termasuk bidang muamalah maka berlaku kaedah bahwa suatu muamalah itu pada dasarnya sah

${ }^{23} \mathrm{Ibid}$,

${ }^{24}$ Ibid., h. 141.

${ }^{25}$ Birgit Krawietz, "Darura in Modern Islamic Law: The Case of Organ Transplantation", dalam Robert Gleave \& Eugenia Kermeli (eds), Islamic Law Theory and Practice (London: I.B. Tauris Publishers, 2001), h. 186.

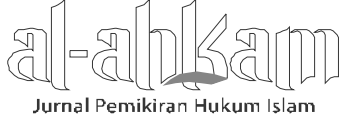


hukumnya kecuali ada dalil yang mengharamkannya. ${ }^{26}$ Ketika pendekatan tațīq melalui prinsip așliyyah ini dierapkan secara berlebihan, maka akan mengabaikan pertimbangan tațbīq melalui tujuan Syara' (maqāșid al-sharīah). Padahal, karakter dasar muamalah ada pada prinsip atau tujuan muamalah bukan pada rumusan zahir-nya. Jika prinsip atau tujuan muamalah ini diabaikan maka aplikasi fikih muamalah kehilangan ruh ke-Islamannya dan bisa membuka peluang menguntungkan satu pihak saja.

\section{Variasi Model Aplikasi Fikih Muamalah Modern}

Variasi kecenderungan corak aplikasi fikih muamalah modern dapat dieksplorasi sejak awal kemunculan perbankan syari'ah. Pada awalnya ada kecenderungan aplikasi fikih muamalah secara idealis, seiring dengan semangat neo-revivalis (membangkitkan kembali ajaran Islam di bidang ekonomi). Kemunculan perbankan Islam merupakan salah satu realisasi dari suatu pemikiran untuk membentuk kembali perekonomian berdasarkan Islam. Pemikiran ini tidak terlepas dari semangat kebangkitan kembali Islam yang dapat dilihat di segenap dunia Islam. Sektor uang, perbankan dan investasi dianggap sebagai hal yang paling penting bagi proses Islamisasi ekonomi. Perbankan modern yang berlandaskan bunga serta condong menguntungkan kaum kapitalis dan kaum hartawan telah ditolak dan dianggap sebagai perbankan yang tidak islami karena adanya larangan yang jelas dari al-Qur'an atas riba yang ditafsirkan sebagai larangan terhadap semua bentuk bunga, rente atau sebangsanya apapun jenis dan fungsi dari suatu pinjaman. ${ }^{27}$

Penolakan atas bunga ini memunculkan pertanyaan tentang apa yang dapat menggantikan mekanisme penerapan suku bunga dalam sebuah kerangka kerja Islam, dan jika pembayaran dan penarikan bunga dilarang maka bagaimana bankbank Islam beroperasi. Dipakailah sistem bagi hasil (Profit and Loss Sharing (PLS) atau bagi-untung-dan-rugi) sebagai metode alokasi sumber daya, menggantikan sistem bunga. Bank Islam tidak membebankan bunga melainkan mengajak partisipasi dalam bidang usaha yang didanai. ${ }^{28}$ Penekanan pada kerja sama dalam

\footnotetext{
${ }^{26}$ Amir Muallim dan Yusdani, Konfigurasi Pemikiran Hukum Islam (Yogyakarta: UII Press Indonesia, 1999), h. 44.

${ }^{27}$ Muhammad Nejatullah Siddiqi, Issues in Islamic Banking, terj. Asep Hikmat Suhendi (Bandung: Penerbit Pustaka, 1984), h. xiii.

${ }^{28}$ Latifa M. Algaoud \& Mervyn K. Lewis, Islamic Banking (Cheltenham, UK: Northampton, MA : Edward Elgar, 2001), h. 9, 13.
} 
kehidupan ekonomi berdasarkan prinsip bagi hasil dipandang sebagai alternatif dasar bagi perbankan dan investasi dalam kerangka islam. ${ }^{29}$

Pada perkembangan berikutnya, corak aplikasi fikih muamalah cenderung lebih formalistis tekstualis. Mestinya, secara ideal Bank Syari'ah akan bersifat islami (dalam arti ikut mewujudkan nilai-nilai keadilan ekonomi islam) bila prinsip kemitraan model muḍārabah atau mushārakah ini diterapkan secara konsisten dengan berbagi untung dan rugi dengan nasabah sehingga kemitraan yang seimbang antara bank dengan nasabah dapat terwujud secara adil. Namun idealitas model tersebut tidak akan dapat terlaksana bila diterapkan dalam masyarakat yang belum islami dalam artian masing-masing individu belum memikili moralitas ke-islaman semisal sifat amanah. Sebagai lembaga bisnis, untuk tetap eksis bank syari'ah dituntut dapat menghasilkan keuntungan, dan karena berlabelkan islam, maka bank harus mengambil pijakan pada aturan-aturan Hukum Islam. Sementara dalam khazanah fikih muamalah sudah tersedia berbagai macam akad yang bisa diadopsi untuk menjalankan fungsi perbankan. Perkembangan perbankan syari'ah kemudian diwarnai aplikasi hybrid contract, perpaduan berbagai akad yang ada dalam fikih muamalah klasik.

Corak aplikasi fikih muamalah pada hybrid contract lebih bersifat formalistis, karena dalam rumusannya lebih banyak dipakai rambu-rambu syarat rukun akad secara formal. Ketika dijumpai Hadis yang melarang multiakad maka itu dispesifikkan secara kasuistis pada apa yang disebutkan dalam Hadis tersebut, tidak dicoba dijelaskan reasoning makna di balik pelarangan tersebut, seperti yang ditegaskan oleh pihak pendukung hybrid contract. Dengan kata lain, aplikasi fikih muamalahnya lebih bersifat formalistis literalis, tidak bersifat substansialis yang semestinya menjadi jiwa pengembangan fikih muamalah yang berbeda dengan fikih ibadah. Kalau dalam fikih ibadah, tinggal mengamalkan teks naș-nya, sedangkan dalam fikih muamalah diperlukan penafsiran atau penggalian akan substansi maknanya. Pemberlakuan fikih muamalah dengan corak formalistis literalis bisa membuka peluang hilah atau reka daya hukum, di mana dengan tetap berlindung di balik formalitas teks fikih, direkadaya untuk kepentingan pihak-pihak tertentu saja dan mengabaikan maqāṣid al-sharïyyah di balik tekstulitas naṣ hukum. Kecenderungan corak formalistis tekstualis tersebut tampak pada formulasi hybrid contract yang berbentuk akad murābahah terpadu atau bay' bi thaman 'äjil dan ijārah muntahiyah bi 'l-tamlīk.

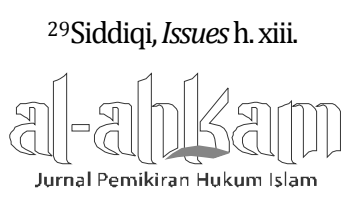

Volume 23, Nomor 2, Oktober 2013 
Kecenderungan aplikasi fikih muamalah yang terlalu formalistis tekstualis tentu banyak mendapat kritikan sebagaimana kritikan yang banyak dialamatkan pada akad bay' bi thaman 'âjil di Malaysia. Pada perkembangan berikutnya muncul pemikiran untuk formulasi hybrid contract yang lebih seuai dengan tujuan syari'ah di bidang ekonomi, sebagaimana nampak pada formulasi mushārakah mutanāqișah. Formulasi ini dibentuk dengan mengupayakan terwujudnya prinsip kemitraan yang berkeadilan antara bank dan nasabah. Beberapa penelitian ${ }^{30}$ yang mengkomparasikan antara bay' bi thaman 'ājil dengan mushārakah mutanāqișah di Malaysia banyak menyimpulkan bahwa mushārakah mutanāqișah lebih adil dan lebih sesuai dengan syari'ah.

\section{Kesimpulan}

Formulasi hybrid contract dari sisi latar belakang perumusannya didorong oleh semangat mengembangkan perbankan syari'ah dengan tetap memiliki kaitan dengan fikih. Ketika akad tunggal mushārakah atau mud̄ārabah kurang fleksibel untuk diterapkan dan kurang menjamin keuntungan dan perkembangan Bank Syari'ah, diformulasikanlah hybrid contract berupa bay' bi thaman 'ājil atau murābaḥah kombinasi sebagai kompetitor pinjaman berbasis bunga. Demikian juga ijārah muntahiyah bi 'l-tamlīk dimunculkan sebagai kompetitor akad sewa beli yang disyari'ahkan lewat hybrid contract. Pengembangan berikutnya dilatarbelakangi oleh berbagai kritik kesyari'ahan atas hybrid contract sebelumnya, sehingga ada keinginan untuk membuat hybrid contract yang lebih merepresentasikan nilai-nilai syari'ah.

Kecenderungan aplikasi fikih muamalah pada formulasi hybrid contract lebih nampak sebagai model aplikasi fikih dalam bentuk takhayyur, yang tidak terikat pada mazhab tertentu, tetapi lebih memilih mana pendapat klasik yang sesuai dengan alasan tertentu. Namun, secara umum kecenderungan corak formulasi hybrid contract lebih bersifat formalistis tekstualis. Corak formalistis nampak pada berbagai ketentuan atau rambu-rambu pelaksanaannya yang sangat berpegang pada formalitas syarat rukun akad yang sudah diformulasikan pada fikih muamalah klasik. Corak tekstualis karena perhatian besarnya terhadap penafsiran

\footnotetext{
${ }^{30}$ Lihat misalnya: Mydin Meera, Ahamed Kameel and Abdul Razak, Dzuljastri (2005) Islamic home financing through Mushārakah Mutanāqișah and al-Bay' bi thaman 'Äjil contracts: a comparative analysis. Review of Islamic Economics, 9 (2), h. 5-30. ISSN 0962-2055, http://www.islamicfoundation.org.uk/User/Journals, diakses 12 Agustus 2013.
} 
literal teks hukum yang sudah ada. Pada dasarnya karakter dasar muamalah ada pada prinsip atau tujuan muamalah bukan pada rumusan zahir-nya. Jika prinsip atau tujuan muamalah ini diabaikan maka aplikasi fikih muamalah kehilangan ruh ke-islamiannya dan bisa membuka peluang menguntungkan satu pihak saja. Namun demikian, ada sisi harapan positif karena kecenderungan model aplikasi fikih muamalah mulai bergeser ke corak yang lebih substansialis dengan munculnya mushārakah mutanāqișah, yang awal kemunculannya dari dunia kampus. [a]

\section{DAFTAR PUSTAKA}

Fatwa Dewan Syari'ah Nasional (DSN) Majelis Ulama Indonesia (MUI) No. 27/DSNMUI/III/2002 tentang al-Ijārah al-Muntahiyah bi 'l-Tamlik.

Fatwa Dewan Syari'ah Nasional (DSN) Majelis Ulama Indonesia (MUI) No.: 73/DSN-MUI/XI/2008 tentang Mushārakah Mutanaqisah.

Gleave, Robert \& Eugenia Kermeli (eds), Islamic Law Theory and Practice, London: I.B. Tauris Publishers, 2001.

Huda, Nurul \& Mohamad Heykal, Lembaga Keuangan Islam Tinjauan Teoritis dan Praktis, Jakarta: Kencana, 2010.

International Review of Business Research Papers Volume 6. Number 2. July 2010.

al-Khālifi, Riyāḍ Manșūr, "al-Maqāṣid al-Shar'iyyah wa Athāruhā fỉ Fiqh al-Mu'āmalāt al-Māliyyah" dalam Majalah Jāmi'ah al-Mālik 'Abd al-'Azīz, Al-Iqtiṣād al-Islāmī, 17, 1, 2004.

Latifa M. Algaoud \& Mervyn K. Lewis, Islamic Banking, Cheltenham, UK; Northampton, MA: Edward Elgar, 2001,

Muallim, Amir dan Yusdani, Konfigurasi Pemikiran Hukum Islam, Yogyakarta: UII Press, 1999.

Mohammad Osmani, Noor dan Md. Faruk Abdullah, "Mushārakah Mutanāqisah Home Financing: A Review of Literatures and Practices of Islamic Banks In Malaysia" dalam International Review of Business Research Papers Vol. 6. Number 2. July 2010, h.

Rindjin, Ketut, Pengantar Perbankan dan Lembaga Keuangan Bukan Bank, Jakarta: Gramedia Pustaka Utama, 2000.

ash-Shiddieqy, Teungku Muhammad Hasbi, Pengantar Fikih Muamalah, Semarang: Pustaka Rizki Putra, 1999.

Siddiqi, Muhammad Nejatullah, Issues in Islamic Banking, terj. Asep Hikmat Suhendi, Bandung: Penerbit Pustaka, 1984.

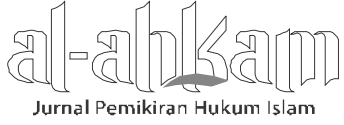


Ali Murtadho

Syafe'i, Rachmat, Fikih Muamalah, Bandung: Pustaka Setia, 2001.

Shindī, Ismāî̀, al-Mushārakah al-Mutanāqiṣah fi al-'Amal al-Mașrafi al-Islāmī-Taș̣̄l wa Dabt, Palestina: Universitas al-Khalīl, 2009.

al-Zuhaylī, Wahbah, al-Mu'āmalah al-Māliyyah al-Mu'āṣirah Buhūth wa Fatāwā wa Hulūl, Beirut: Dār al-Fikr, 2002.

Internet:

Firdaus Muhammad Arwan, Ijārah Muntahiyah bi 'l-Tamlīk Sebagai Konstruksi Hukum Perjanjian Sewa Beli dalam Ekonomi Islam, dalam http://www. badilag.net, diakses 10 Agustus 2013.

Hasanudin, "Multi Akad dalam Transaksi Syari'ah Kontemporer pada Lembaga Keuangan Syari'ah di Indonesia: Konsep dan Ketentuan (Dawābit) dalam Perspektif Fikih", http://www. ekonomisyari'ah.org/, diakses 10 Agustus 2013.

Mydin Meera, Ahamed Kameel and Abdul Razak, Dzuljastri (2005) Islamic home financing through Mushārakah Mutanāqișah and al-Bay' bi thaman 'Ājil contracts: a comparative analysis. Review of Islamic Economics, 9 (2), h. 530. ISSN 0962-2055, http://www.islamic-foundation.org.uk/User/Journals, diakses 12 Agustus 2013.

Nadratuzzaman Hosen, M., "Mushārakah Mutanāqiṣah", dalam http://www. ekonomisyari'ah.org, diakses 10 Agustus 2013.

142 || Volume 23, Nomor 2, Oktober 2013

Jurnal Pemikiran Hukum Islam 